Egyptian Journal of Aquatic Biology \& Fisheries

Zoology Department, Faculty of Science,

Ain Shams University, Cairo, Egypt.

ISSN $1110-6131$

Vol. 25(2): 561 - 572 (2021)

www.ejabf.journals.ekb.eg

\title{
Marketing Efficiency of the Climbing Perch (Anabas testudineus) Cultured with Bioflock System
}

\author{
Ahmadi *, Emmy Lilimantik and Emmy Sri Mahreda \\ Faculty of Marine and Fisheries, Lambung Mangkurat University, Indonesia. \\ *Corresponding Author: ahmadi@ulm.ac.id
}

\section{ARTICLE INFO}

Article History:

Received: April 16, 2020

Accepted: March 30, 2021

Online: April 22, 2021

Keywords:

Bioflock system,

Anabas testudineus,

Climbing perch,

farmer's share,

marketing channel,

marketing margin

\section{ABSTRACT}

The present study aimed to investigate the marketing channels, marketing margin, and farmer's share of the climbing perch (Anabas testudineus) cultured with bioflock system. The fish were daily marketed in South and Central Kalimantan of Indonesia through two marketing channels i.e. the first channel: fish farmers $\rightarrow$ wholesalers $\rightarrow$ retailers $\rightarrow$ end consumers; and the second channel: fish farmers $\rightarrow$ institutional market $\rightarrow$ end consumers. The fish prices at fish farmers, wholesalers, and retailers were IDR 60,000, IDR 70,000, and IDR 77,667 per $\mathrm{kg}$, respectively. In the first channel, the highest net profit was received by fish farmers (45\%), followed by wholesalers $(33 \%)$ and retailers $(22 \%)$. While in the second channel, the restaurant earns profit (74\%) almost 3 times higher than fish farmers (26\%). The marketing margins of wholesalers, retailers,s and restaurants were $14 \%$, $23 \%$, and $50 \%$, respectively. The current marketing system was considered efficient (farmer's share $=77.25 \%$ ). Fish farming and culinary could be a promising business opportunity due to the high demand for this species.

\section{INTRODUCTION}

Indonesia is the world's largest archipelago state , and nowadys it is the second largest global fish producer (Suadi \& Kusano, 2019). The fishery sector contributes about $8 \%$ of national gross domestic product. More than 11 million people are working in this sector as fishermen (8.69\%), fish farmers (35.06\%), fish processors and fish marketers (55.84\%), and salt farmers $(0.41 \%)$ (Suraya \& Sulistyo, 2019). Fish consumption increased from $47.34 \mathrm{~kg}$ to $50.69 \mathrm{~kg}$ per capita, as estimated in one year. Nowadays, perception of consumer preferences for consuming fish is highly appreciated (Esilaba et al., 2017). Fish consumption preferences are affected by individuals' socioeconomic characteristics (Can $\boldsymbol{e t}$ al., 2015). Consuming fish is very good for health as fish provides essential amino acid, calcium, phosphorus, iron, zinc, copper and vitamins (Rahman et al., 2012; Tilami \& Sampels, 2017). Fish contains $19.50 \%$ protein and 2.27\% lipid (Ahmed et al., 2012). 
In South Kalimantan province, climbing perch (Anabas testudineus) is locally known as "Papuyu", and favorably considered as one of the commercially important freshwater fish species (Ahmadi, 2019). The fish are usually served as delicious food with high quality meat. The market demand for fish consumption continuously increase, meanwhile the market supply is still low in quantity. After all, freshwater fish marketing is a crucial moment of success for producers and traders to earn the profit since fish, being a highly perishable commodity, needs immediately processing or selling after harvest. It spoils soon after death due to microbial actions, which results in disagreeable taste, smell and texture thereby reducing consumer acceptability (Garrow \& James, 1994). Meanwhile the fish price fluctuates much depending on the season, the quantity and quality of fish, the type and size of fish, freshness, supply and demand, market structure, market distance, and also long-short marketing channels (Aswathy \& Abdu Samad, 2013; Ali et al., 2014; Begum et al., 2014). Nowadays, business transaction can be done through fish market, retail market, fishing port or even via internet order.

Numerous studies have been well-documented to describe the overview of freshwater and marine fish marketing including marketing system (Husen, 2019), marketing channels (Ali et al., 2014; Rahman et al., 2019), marketing management (Sathiadhas \& Kanagam, 2000), market intermediaries and marketing margins (Hussain et al., 2003), market integration (Omar et al., 2014), typical transportation system used (Rokeya et al., 1997), economic analysis of fresh fish marketing (Ali $\boldsymbol{e t}$ al., 2008), and marketing strategy (Ahmed and Hossain, 2012). All fish marketed here are in the form of live fish, fresh fish, smoked and frozen fish sourced from capture fishery, aquaculture and fish processing. Basically the marketing system is the exchange activities associated with transferring property rights to commodities, physically purchasing and allocating resources, handling of products, disseminating information to participants and institutional arrangements for facilitating these activities (Hossain et al., 2015). In the present study, the marketing channels was investigated for the climbing perch (Anabas testudineus) held from bioflock system-based fish farming down to the end consumers, including farmer share and the profit gained at different levels of marketing. In addition, specific suggestions were provided to improve the marketing system in this area of study.

\section{MATERIALS AND METHODS}

\section{1. $\quad$ Research Sites}

The research activities started from the field survey to five fish farming sites in Banjarbaru, and then moved into six local fish markets located in Banjarbaru, Binuang, Rantau, Barabai, Pelaihari of South Kalimantan province, addingly Kapuas of Central Kalimantan, Indonesia (Fig. 1). These locations were purposively selected to exemplify the business prospect, marketing channels and distribution of the climbing perch at different levels. 


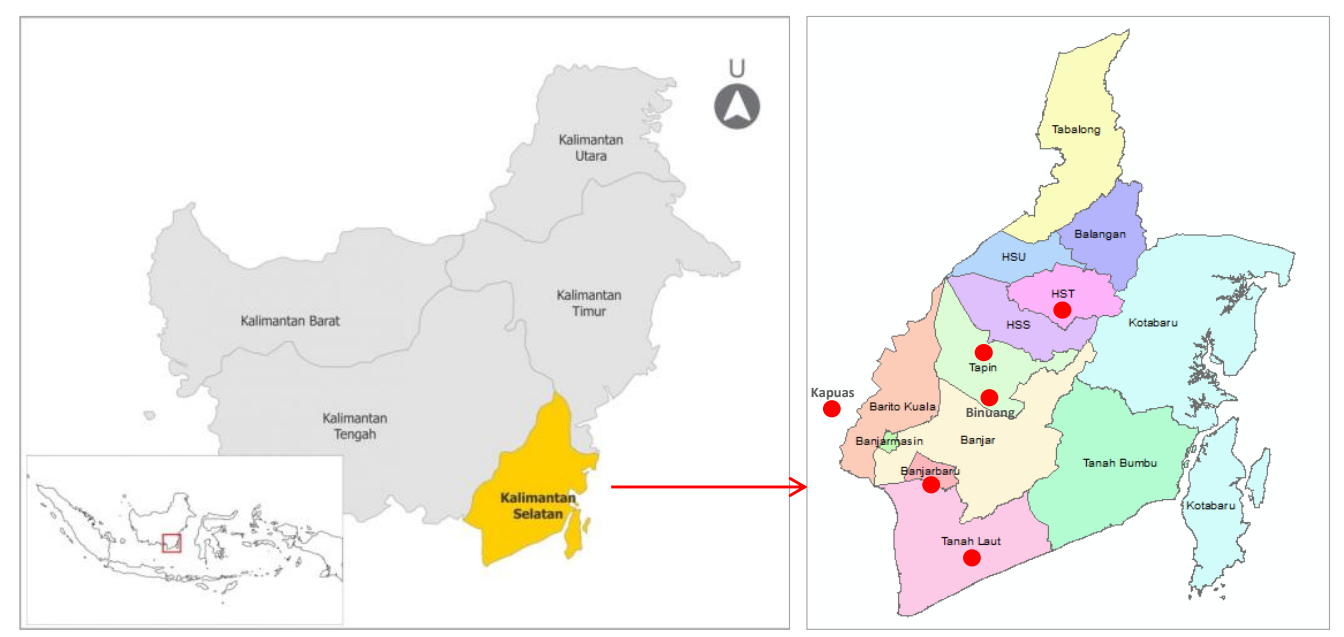

Fig. 1. The map showing the sampling areas for the climbing perch marketing

\section{Characteristic of Respondents}

A total of 22 respondents who directly involved in marketing channels were selected comprising 5 fish farmers, 2 fish collector traders and 15 retailers. The ages of respondents varied between 44-51 year olds with the duration of business of 2-4 years. The wholesalers and retailers were determined by the snowball sampling method. Snowball sampling is a purposeful method of sampling in qualitative research (Naderifar et al., 2017). The respondents were interviewed using the structured questionnaires. The deep interview was undertaken to get an overview and a reliable information on the existing fish distribution and marketing systems, marketing channels, and also the facing constraints.

\section{Marketing Margin}

Marketing margin is the difference between the price at the fish farmer level and the price at the end consumer level. It can simply be expressed with the following formula (Flowra et al., 2012):

$$
\mathrm{MM}=\mathrm{Pr}-\mathrm{Pf}
$$

where: $\mathrm{MM}$ is marketing margin (IDR), Pr is the price at the end consumer (IDR) and Pf is the price at fish farmer (IDR). It can also be calculated using the following formula (Rahman et al., 2012):

Marketing margin $(\%)=($ Selling price - Purchase price $) /$ Selling price $\times 100$

\section{Farmer's Share}

The farmer's share is the ratio of price received by the fish farmer to the price paid by the end consumer. It can be calculated using the formula of Saravanapandeeswari and Vanitha (2017):

$$
\mathrm{Fs}=\mathrm{Fp} / \mathrm{Cp} \times 100
$$


where: Fs is the farmer's share (\%), Fp is the farmer's price (IDR/kg), and Cp is the consumer's price (IDR/kg). According to Kohls and Downey (1985), if the portion of the price received by fish farmer is greater than $50 \%$, then the marketing system can be considered efficient. The data were tabulated and analyzed using conventional statistical tools of MS Excel 2010, then presented in textual, charts and tabular forms.

\section{RESULTS AND DISCUSSION}

There was about $60-240 \mathrm{~kg}$ of fish harvested by individual fish farmer during 8 months of cultured period (Table 1). The sizes of fish varied between 120 and $300 \mathrm{~mm}$ total length, and between 35 and $125 \mathrm{~g}$ weight. The fish were typically harvested and sold on the same day. When the fish price was set at IDR 60,000 per $\mathrm{kg}$, the fish farmers received about IDR 3,600,000 to $14,400,000$. Of $720 \mathrm{~kg}$ of total fish, $672 \mathrm{~kg}(93.33 \%)$ was shared to the wholesalers and the rest $48 \mathrm{~kg}(6.67 \%)$ was given to the local restaurants. In the first channel, there were only two wholesalers, who collected the fish directly from fish farmers to the number of $162-510 \mathrm{~kg}$ to be distributed to 15 retailers (6$8 \mathrm{~kg}$ per day or $42-56 \mathrm{~kg}$ per week per individual). With the selling price of IDR 70,000 per $\mathrm{kg}$, the wholesaler's revenue ranged from IDR 11,340,000 to IDR 35,700,000. At retail prices of IDR 75,000-80,000 per $\mathrm{kg}$, each individual retailer receives income ranging from IDR 450,000 to IDR 640,000 per day depending on the quantity of fish sold out to the end consumers. Among variable cost, pellet and fish seed were the main purchase account to be borne by the fish farmers (30-41\%). While for retailers and wholesalers, it counted for about $93-98 \%$ allocated for buying the fish.

Table 1. The volume and value of fish production at different marketing levels

\begin{tabular}{|c|c|c|c|c|c|c|c|}
\hline \multirow{2}{*}{$\begin{array}{l}\text { Marketing } \\
\text { level }\end{array}$} & \multirow{2}{*}{$\mathrm{n}$} & \multicolumn{3}{|c|}{ Share of production $(\mathrm{kg})$} & \multirow{2}{*}{$\begin{array}{c}\text { Price } \\
\text { (IDR/kg) }\end{array}$} & \multicolumn{2}{|c|}{ Revenue (IDR) } \\
\hline & & Quantity & Average & Total & & Average & Total \\
\hline Fish farmers & 5 & $60-240$ & 144 & $720^{11}$ & 60,000 & $8,640,000$ & $43,200,000$ \\
\hline Wholesalers & 2 & $162-510$ & 336 & 672 & 70,000 & $23,520,000$ & $47,040,000$ \\
\hline Retailers & 15 & $42-56^{2)}$ & 44.8 & 672 & 77,667 & $3,479,482$ & $52,192,224$ \\
\hline
\end{tabular}

The market demand for the climbing perch fish consumption reaches $900 \mathrm{~kg}$ per day, which is almost entirely sourced from the wild and only $30 \%$ produced from fish farming. In line with population growth and economy improvement, it is predicted that market need of the climbing perch, to meet fish consumption for the next 5 years, ranges from 1.5 to 2 tons per day. The bioflock technology in the aquaculture system had been successfully applied for some commercial fish and shrimp species such as the Nile tilapia (Nahar et al., 2015), African catfish (Ekasari et al., 2016), pink shrimp (Emerenciano et al., 2013), the pacific white shrimp (Da Silva et al., 2013), Japanese tiger prawn (Zhao et al., 2012), the green tiger shrimp (Megahed, 2010), Malaysian prawn (Perez-Fuentes et al., 2013), the giant tiger prawn (Anand et al., 2014) and most recently applied for the 
climbing perch cultured in the ponds and business with a favorable prospect (Izmaniar $\boldsymbol{e t}$ al., 2018).

\section{Marketing Channels}

There were two marketing channels for bioflock system-based climbing perch cultured (Fig. 2). The first channel, four of five fish farmers sold out the fish to the wholesalers $(80 \%)$, and then distributed to the 15 retailers and finally marketed to the end consumers. The second channel, one fish farmer sold out the fish through institutional market/the restaurant (20\%) and then directly distributed to the end consumers. The basic reasons why most of fish farmers preferred the first channel are as follows: (1) fish farmers do not need to bear the transportation costs and other risks; (2) there are still many farmers who depend on fish traders to market their fish production. Moreover, the presence of fish traders provides convenience for fish farmers during the process of harvesting, payment, transportation and distribution; (3) each fish farmer usually has his own customer (fish trader) so that the sale transaction can work well; (4) fish traders also have the fixed customers (retailers) in some market areas so that the sales process can run quickly and timely. Furthermore, the retailers usually make the payment in cash; (5) there is a commitment and trust between fish farmers and fish traders, especially in terms of payments, which is usually done by fish traders after the fish have been sold out. Remarkably, a partner's reputation in the market has a strong positive impact on the trustbuilding process (Kwon \& Suh, 2004). Thus, success in business is determinable how the key players build a good market communication to generate a sustainable business.

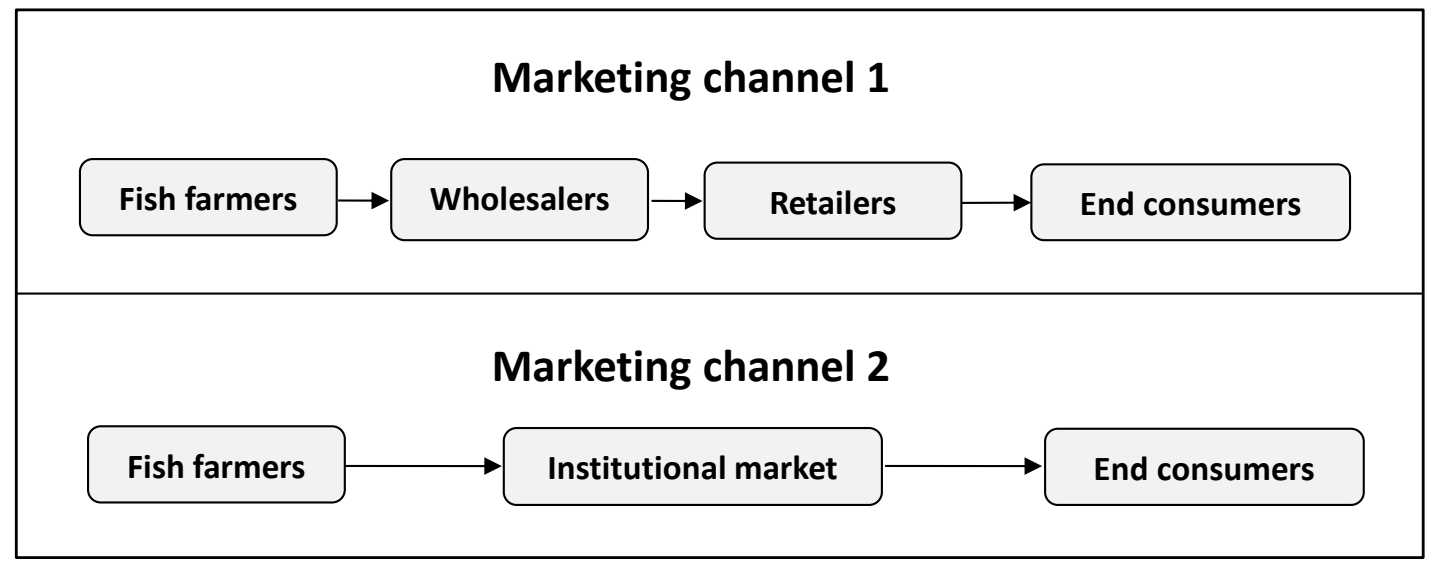

Fig. 2. Marketing channels of the climbing perch from fish farmers to end consumers

\section{2. $\quad$ Marketing Margin}

Marketing margin analysis was performed to see how big the role of market intermediaries as a link between fish farmers and final consumers in influencing the fish price. There was a variation in the fish prices at different marketing channels. The lowest fish price usually goes to the fish farmer level, and then increasingly at the wholesalers or 
institutional market level and terminates in the retailer level that leads to variation in the marketing margin (Table 2). It was estimated that the fish farmers received the net margin of about 18\% of the selling price for their fish production. According to Huger and Hirenath (1984), the higher the value of marketing margin, the lower the efficiency of the marketing system becomes. Rabby et al. (2015) assumed that the producers and intermediaries could be more benefited financially, if efficient marketing was arranged properly. In wholesale market, marketing intermediaries usually perform important role by providing financial assistance, inputs and other marketing facilities to the farmers since their motive is also profit oriented (Keno, 1994). Otherwise generally felt by the consumers is that they have to pay higher price due to the involvement of too many intermediaries in the marketing channels.

In the first channel, there was a difference in the price (IDR 17,666 per $\mathrm{kg}$ ) between the price at fish farmers (IDR 60,000 per kg) and the average price at the end consumers (IDR 77,666 per kg). The percentages of marketing margin for the wholesalers to the fish farmers, the retailers to the fish famers and the retailers to the wholesalers were $14.29 \%$, $22.75 \%$ and $9.78 \%$ respectively. It was clearly pointed out that the wholesalers had margin (IDR 10,000 per $\mathrm{kg}$ ) greater than retailers (IDR 7.666 per $\mathrm{kg}$ ), this was because: (1) they acted as the price maker in the marketing system since they have a good marketing intelligence; (2) they sold out the fish in large quantity in order to reduce the marketing cost; while (3) retailers sold out the fish in small quantity resulted in the marketing cost that was relatively high. At the same time, the amount of marketing costs paid by the wholesalers (IDR 2,050 per $\mathrm{kg}$ ) was lower than that paid by retailers (IDR 2,456 per $\mathrm{kg}$ ); this was because they do not need to pay for stall rental cost, market retribution or other relevant services. In the first channel, the highest net profit was received by fish farmers (45\%), followed by wholesalers (33\%) and retailers $(22 \%)$. While in the second channel, the restaurant earn profit (74\%), almost 3 times higher than fish farmers $(26 \%)$, corresponding to marketing cost spent. It was calculated that the marketing margin of restaurant to fish farmer was $50 \%$ (see Table 2). The profit received by the wholesalers (IDR 7,950 per $\mathrm{kg}$ ) was comparatively higher than that received by retailers (IDR 5,210 per $\mathrm{kg}$ ). It means that the market intermediaries can be assumed efficient because they create the business much more profitable. Aktar et al. (2013) reported that, $80 \%$ of the fish retailers in Noakhali district of Bangladesh have improved their livelihood status through fish trading. Omar et al. (2014) suggested that efficient marketing system should be developed by reducing marketing cost and increasing marketing services to make the business more profitable. Moreover, the fish farmers should also follow standard scientific culture practices, and regularly access information on the fish prices (Kumar et al., 2010). 
Table 2. Market prices, marketing margin and farmer's share for the climbing perch at different levels of marketing channels

\begin{tabular}{|c|c|c|c|}
\hline \multirow{2}{*}{$\begin{array}{l}\text { Marketing } \\
\text { Level }\end{array}$} & \multirow{2}{*}{ Parameter Observed } & \multicolumn{2}{|c|}{ Marketing Channel } \\
\hline & & 1 & 2 \\
\hline \multicolumn{4}{|c|}{ Fish farmers } \\
\hline & Production cost (IDR/kg) & $49,225.52$ & $49,225.52$ \\
\hline & Selling price (IDR/kg) & $60,000.00$ & $60,000.00$ \\
\hline & Marketing margin (IDR/kg) & $10,774.48$ & $10,774.48$ \\
\hline & Marketing cost (IDR/kg) & - & - \\
\hline & Profit (IDR/kg) & $10,774.48$ & $10,774.48$ \\
\hline \multicolumn{4}{|c|}{ Wholesalers } \\
\hline & Purchase price (IDR/kg) & $60,000.00$ & \\
\hline & Selling price (IDR/kg) & $70,000.00$ & \\
\hline & Marketing margin (IDR/kg) & $10,000.00$ & \\
\hline & Marketing cost (IDR/kg) & $2,050.32$ & \\
\hline & Profit (IDR/kg) & $7,949.68$ & \\
\hline & Margin of wholesaler to fish farmer $(\%)$ & 14.29 & \\
\hline \multicolumn{4}{|l|}{ Retailers } \\
\hline & Purchase price (IDR/kg) & $70,000.00$ & \\
\hline & Selling price (IDR/kg) & $77,666.67$ & \\
\hline & Marketing margin (IDR/kg) & $7,666.67$ & \\
\hline & Marketing cost (IDR/kg) & $2,456.00$ & \\
\hline & Profit (IDR/kg) & $5,210.67$ & \\
\hline & Margin of retailer to fish farmer $(\%)$ & 22.75 & \\
\hline \multicolumn{4}{|c|}{ Restaurant (Institutional market) } \\
\hline & Purchase price (IDR/kg) & - & $60,000.00$ \\
\hline & Selling price (IDR/kg) & & $120,000.00$ \\
\hline & Marketing margin (IDR/kg) & & $60,000.00$ \\
\hline & Marketing cost (IDR/kg) & & $29,000.00$ \\
\hline & Profit (IDR/kg) & & $30,500.00$ \\
\hline & Margin of restaurant to fish farmer $(\%)$ & & 50.00 \\
\hline \multicolumn{4}{|l|}{ Consumers } \\
\hline & Purchase price (IDR/kg) & $77,666.67$ & $120,000.00$ \\
\hline & Total margin (IDR/kg) & $28,441.15$ & $10,774.48$ \\
\hline & Total marketing cost (IDR/kg) & $4,506.32$ & $29,000.00$ \\
\hline & Total profit (IDR/kg) & $23,934.82$ & $41,274.48$ \\
\hline & Farmer's share $\rightarrow$ efficient (Fs $>50 \%$ ) & 77.25 & 50.00 \\
\hline
\end{tabular}

\section{Farmer's Share}

The selling price of fish at fish farmers was IDR 60,000 per $\mathrm{kg}$, while the price at retailer level fell between IDR 75,000 to IDR 80,000 per $\mathrm{kg}$ or IDR 77,666 per $\mathrm{kg}$ in average. The price portion received by the fish farmers recorded values with ranges 75 $80 \%$ or about $77.25 \%$ of the price paid by the end consumers (Table 2). This, in return, 
was found higher than $50 \%$, indicating that fish marketing system was considered efficient (Kohls \& Downey, 1985). Compared to other single-species from different geographical areas, the percentage of farmer's share obtained in the present study was equal to the trout marketing in Kohgiloye and Boyer Ahmad province of Iran (Shahi et al., 2012), but it was higher than European anchovy (54\%) or Atlantic horse mackerel (60\%) traded in Trabzon province (Dağtekin, 2010).

The great portion of the price received by fish farmers was closely related to the marketing system itself that has been formed between them and wholesalers. This was due to some reasons: (1) fish farmers willing to get greater profits with zero risk; (2) since fish farmers have a limited fish production, it was better to sell out the fish directly to the wholesalers rather than the retail market. In addition, (3) fish farmers have also the bargaining power to determine a reasonable price based on the quality and size of fish because they also knew well about the market price of this species being an important food fish. Such bargaining interaction was also shown by both the aquafarmer's association in Thambikottai village of Tiruvarur district and fishermen associations in Kombuthurai, Tamil Nadu of India (Kumar et al., 2010). Market information is needed by the fish farmers as a part of market transparency and also as a reference for arranging a competitive pricing strategy. In this regard, there was a good lesson learned from aquachoupals model in Andhra Pradesh of India that provides access to prices on a daily basis, in which the farmers are able to take critical decisions on when and where to sell their productions (Kumar et al., 2010). A tangible deliverable maketing system was also demonstrated by Ghana's farmers who received significantly higher prices for their productions after using mobile phone-based marketing information services (MIS) program. This shows how information affects a farmer's decision to sell at the farmgate rather than at the market (Courtois \& Subervie, 2014). In the present study, the retailers had more bargaining power as they sold out the fish to consumers that they purchased from wholesalers, because the bargaining power between retailers and wholesalers is almost equal, as well as the bargaining power between fish farmers and wholesalers. Dealing with the purchase ability of the party, most of wholesalers and retailers use their own capital to do business. It was similarly reported by Jamali et al. (2013) that, about $70 \%$ retailers in Gopalpur Upazila of Tangail district used their own money for fish trading.

\section{Constraint and Solution}

At the fish farmer level, some constraints are encountered that are crucial to success such as; the availability of superior fish seeds, electrical supply and the limited capital for fish production. For the wholesalers, it takes time to collect the harvested fish since the fish farming sites are scattered. Moreover, asynchronous fish harvested by individual fish farmer result in high cost of fish marketing. While for the retailers, the quantity of fish which is shared by the wholesalers does not correspond with the retailer's demand, 
because the supply of fish obtained from the fish farmers is still lacking. Occasionally, if there is more demand of fish among the retailers, the wholesalers prefer to deliver the fish to a location close to fish farming to reduce marketing costs. Specific suggestions to improve the current marketing systems should incorporate: the certified fish hatchery to produce superior seeds, improvement of bioflock technology for small scale fish farming to increase fish production, introduction of modern wholesaling and retailing facilities, the strengthening of institutional marketing, and promotion of mobile phone-based marketing information services to find out the global and local market transparency. In the long term, it is necessary for interested parties to form the cooperative society with legal entity. In this context, the defined role of the cooperative society would support fish marketing system as a whole (Rabby et al., 2015).

\section{CONCLUSION}

It can be concluded that the fish marketing channel through market intermediaries was less efficient than through institutional market. The highest net profit per $\mathrm{kg}$ was received by the fish farmers followed by the wholesalers and retailers. The marketing margin of institutional market was 2-3 times higher than that of wholesalers and retailers. The current marketing system is considered efficient. It is a great challenge to increase fish production since the prospect of culinary business is open. Notably, the present study provides the first reference on the bioflock system-based fish marketing of the climbing perch in the investigated areas.

\section{REFERENCES}

Ahmadi. (2019). Morphometric characteristic and growth patterns of Climbing perch (Anabas testudineus) from Sungai Batang River, Indonesia. Int. J. Hydrol., 3(4): 270-277.

Ahmed, S. and Hossain, B. (2012). Marketing strategies for frozen fish exporters in Bangladesh. J. Arts. Sci. Commer. 3(3): 1-8.

Ahmed, S., Rahman, A.F.M.A.; Mustafa, M.G.; Hossain, M.B. and Nahar, N. (2012). Nutrient composition of indigenous and exotic fishes and rainfed waterlogged paddy fields in Lakshmipur, Bangadesh. World J. Zool., 7(2): 135-140.

Aktar, N.; Islam, M.R.; Hossain, M.B. and Rahman, M. (2013). Fish species availability and marketing system of fish in different markets of Noakhali district in Bangladesh. World Appl. Sci. J., 22(5): 616-624.

Ali, E.A.; Gaya, H.I.M. and Jampada, T.N. (2008). Economic analysis of fresh fish marketing in Maiduguri Gamboru market and Kachallari Alau Dam landing site of Northeastern Nigeria. J. Agric. Soc. Sci., 4: 23-26.

Ali, M.M.; Rahman, M.M.; Hossain, M.Y.; Rahman, M.Z.; Hossen, M.A.; Naser, S.M.A.; Islam, R.; Subba, B.R.; Masood, Z. and Hoque, M.A. (2014). Fish marketing system in southern Bangladesh: recommendations for efficient marketing. Our Nature.12(1): 28-36. 
Anand, P.S.S.; Kohli, M.P.S.; Kumar, S.; Sundaray, J.K.; Roy, S.D.; Venkateshwarlu, G.; Sinha, A. and Pailan, G.H. (2014). Effect of dietary supplementation of biofloc on growth performance and digestive enzyme activities in Penaeus monodon, Aquaculture, 418: 108-115.

Aswathy, N. and Abdussamad, E.M. (2013). Price behavior and marketing efficiency of marine fish in Tuticorin, Tamil Nadu. J. Fish. Econom. Dev., 13(2): 29-35.

Begum, R.; Akter, T.; Barman, P.P.; Marine, S.S. and Hossain, M.M. (2014). Potential for development of marine fish marketing systems in Chittagong District of Bangladesh. J. Sylhet Agric. Univ., 1(2): 247-252.

Can, M.F.; Gunlu, A. and Can, H. (2015). Fish consumption preferences and factors influencing it. Food Science and Technology (Campinas), 35(2): 339-346.

Courtois, P. and Subervie, J. (2014). Farmer bargaining power and market information services. American J. Agric. Econom., 97(3): 1-25.

Da Silva, K.R.; Wasielesky, W. and Abreu, P.C. (2013). Nitrogen and phosphorus dynamics in the bioflock production of the pacific white shrimp, Litopenaeus vannamei. J. World Aquac. Soc., 44(1): 30-41.

Dağtekin, M. (2010). Fishery production and marketing structure in Trabzon (MSc Thesis). Çukurova University, Adana, Turkey.

Ekasari, J.; Suprayudi, M.A.; Wiyoto, W.; Hazanah, R.F.; Lenggara, G.S. and Sulistiani, R. (2016). Bioflock technology application in African catfish fingerling production: the effects on the reproductive performance of broodstock and the quality of eggs and larvae. Aquaculture, 464: 349-356.

Emerenciano, M.; Cuzon, G.; Paredes, A. and Gaxiola, G. (2013). Evaluation of bioflock technology in pink shrimp Farfantepenaeus duorarum culture: growth performance, water quality, microorganisms profile and proximate analysis of bioflock. Aquac. Int., 21(6): 1381-1394.

Esilaba, F.A.; Moturi, W.N. and Mokua, M.A. (2017). Urban consumer's fish preferences and the determinants influencing fish selection and consumption: Case study of Nakuru, Kenya. Int. J. Fish. Aquat. Stud., 5(3): 356-360.

Flowra, F.A.; Bashar, A.H.M.; Jahan, K.S.N.; Samad, M.A. and Islam, M.M. (2012). Fish marketing system and socio economic status of Aratdars in Natore and Rajshahi, Bangladesh. J. Our Nature, 10(1): 34-43.

Garrow, J.S. and James, W.P.T. (1994). Human nutrition and dietetics. London, UK: Churchill Livingstone.

Hossain, M.A.; Abdulla-Al-Asif; Zafar, M.A.; Hossain, M.T.; Alam, M.S. and Islam, M.A. (2015). Marketing of fish and fishery products in Dinajpur and livelihoods of the fish retailers. Int. J. Fish. Aquat. Stud., 3(1): 86-92.

Huger, L.B. and Hirenath, K.C. (1984). Efficiency of alternative channels in marketing of vegetables in Belgaum City - A comparison. Indian J. Agric. Econ., 34(3): 192200.

Husen, M.A. (2019). Fish marketing system in Nepal: Present status and Future prospects. Int. J. Appl. Sci. Biotechnol., 7(1): 1-5.

Hussain, S.A.; Badar, H. and Khokhar, S.B. (2003). Market intermediaries and their marketing margins for Inland Fish - A case study of Lahore District. International J. Agric. Biol., 5(1): 73-76. 
Izmaniar, H.; Mahyudin, I.; Agusliani, E. and Ahmadi. (2018). The business prospect of Climbing perch fish farming with bioflock technology at De' Papuyu Farm Banjarbaru. Int. J. Envi. Agric. Biotechnol., 3(3): 1145-1153.

Jamali, A. (2013). Present status of fish marketing in Gopalpur Upazila of Tangail District. J. Aquat. Sci., 1(2): 24-30.

Keno. (1994). Marketing costs of intermediaries in wholesale markets of fruits and vegetables. Technical Bulletin of Faculty of Horticulture, Chiba University, Japan.

Kumar, B.G.; Ravisankarb, T.; Sureshc, R.; Bhattad, R.; Vimalab, D.; Kumaranb, M.; Mahalakshmib, P. and Sivasakthi Devi, T. (2010). Lessons from innovative institutions in the marketing of fish and fishery products in India. Agric. Econom. Res. Rev., 23: 495-504.

Kwon, I.W.G. and Suh, T. (2004). Factors affecting the level of trust and commitment in supply chain management. J. Suppl. Chain Man., 40(2): 4-14.

Megahed, M. (2010). The effect of microbial biofloc on water quality, survival and growth of the green tiger shrimp (Penaeus semisulcatus) fed with different crude protein levels. J. Arab Aquac. Soc., 5(2): 119-142.

Naderifar, M.; Goli, H., and Ghaljaie, F. (2017). Snowball sampling: A purposeful method of sampling in qualitative research. Strides Dev. Med. Edu., 14(3): e67670.

Nahar, A.; Abu, M.; Siddik, B. and Rahman, M.M. (2015). Bioflock technology in aquaculture systems generates higher income in mono-sex Nile tilapia farming in Bangladesh. Adv. Biol. Res., 9(4): 236-241.

Omar, M.I.; Dewan, M.F.; Janifa, U.A. and Hoq, M.S. (2014). Analysis of spatial cointegration and marketing margin of Tilapia (Oreochromis niloticus) fish in some selected areas of Bangladesh. J. Econom. Sustain. Dev., 5(7): 63-70.

Perez-Fuentes, A.; Perez-Rostro, C.I. and Hernandez-Vergara, M. (2013). Pondreared Malaysian prawn Macrobrachium rosenbergii with the bioflock system. Aquaculture, 400-401: 105-110.

Rabby, A.F.; Hossain, M.A.; Alam, M.T.; Uddin, M.S. and Dey, T. (2015). Status and economics of three Upazilla fish markets in Moulavibazar District in Bangladesh. J. Sylhet Agric. Univ., 2(1): 87-95.

Rahman, Ahmadi and Mahreda, E.S. (2019). Marketing channels of marine fish in Banjarmasin fishing port, Indonesia. Int. J. Fish. Aquat. Res., 4(3): 15-22.

Rahman, M.M.; Hossain, M.A.; Fatematuzzhura; Tasnoova, S.; Ahamed, F.; Hossain, M.Y. and Ohtomi, J. (2012). Fresh fish marketing status in the Northwestern Bangladesh: Recommendations for Sustainable Management. Our Nature, 10(1): 128-136

Rahman, M.M.; Bashar, M.A. and Hasan, M.N. (2012). Effects of stocking density on survival, growth and production of Thai climbing perch (Anabas testudineus) under fed ponds. Sains Malaysiana, 41(10): 1205-1210.

Rokeya, J.A.; Ahmed, S.S.; Bhuiyan, A.S. and Alam, M.S. (1997). Marketing system of native and exotic major carps of Rajshahi District. Bangladesh J. Fish., 20(1-2): 99-103.

Saravanapandeeswari, V. and Vanitha, B. (2017). Producer's share in consumer Rupee in the marketing of Banana, Theni District. Int. J. Curr. Sci. Res., 3(7): 1311-1320. 
Sathiadhas, R. and Kanagam, A. (2000). Distribution problems and marketing management of marine fisheries in India. In: "Marine Fisheries Research and Management". Pillai, V.N. \& Menon, N.G. (Eds.). MFRI; Kochi, pp. 858-875.

Shahi, H.M.; Zeratkish, Y. and Foroughi, V. (2012). Factors affecting Trout marketing in Kohgiloye and Boyer Ahmad Province of Iran. J. Food Agri. Envi., 10(1): 248250.

Suadi and Kusano, E. (2019). Indonesian Seafood Supply Chain', in Kusano, E. (ed.), Food Value Chain in ASEAN: Case Studies Focusing on Local Producers. ERIA Research Project Report FY2018 No.5, Jakarta: ERIA, pp.134-163.

Suraya and Sulistyo, P.B. (2019). Sosialisasi identifikasi peluang usaha kelautan dan perikanan di Pesisir Pantai Sawarna -Lebak Banten. Jurnal Abdi MOESTOPO, 2(1): 30-37.

Tilami, S.K. and Sampels, S. (2017). Nutritional value of fish: lipids, proteins, vitamins, and minerals. Rev. Fish. Sci. Aquac., 26(2): 243-253.

Zhao, P.; Huang, J.; Wang, X.H., Song, X.L.; Yang, C.H.; Zhang, X.G. and Wang, G.C. (2012). The application of bioflocs technology in high- intensive, zero exchange farming systems of Marsupenaeus japonicus. Aquaculture, 354-355: 97106. 